\title{
“La Toilette". When a doctor becomes a painter: Frederic Bazille
}

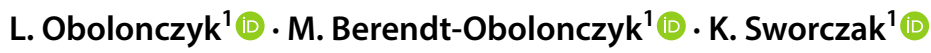

Received: 15 March 2019 / Accepted: 21 March 2019 / Published online: 15 April 2019

(c) The Author(s) 2019

\begin{abstract}
Purpose To find endocrinological disturbances in impressionism.

Patients and methods Analysis of "La Toilette" painting of Frederice Bazille.

Results We present a masterpiece work of Frederic Bazille "La Toilette" where a large goiter is visible. Short description of Bazille's life and painting is included.

Conclusion Despite of unique painting technique, thyroid disorders are visible even in impressionism.
\end{abstract}

Keywords Frederic Bazille $\cdot$ Endocrinology $\cdot$ Painting

Jean Frederic Bazille (1841-1870) was born in Montpellier and grew up in a wealthy, middle class family. His father was a prominent wine dealer. Due to a number of father's connections, young Frederic met an art collector Alfred Bruyas. During this closer relationship, he could admire paintings of, e.g., Delacroix and Corot. First as a spectator, later as a young artist his painting adventure slowly started.

In 1859, Bazille started medical study in Montpellier and since 1862 continued it in Paris. A contact with impressionists as Monet, Renoir and Sisley made him more painter than doctor. He was also known as a great benefactor because of his material support for his friends (especially Monet). In 1864, he finished medical study, but he never worked as a doctor. He died at age of 29 years in Franco-German war [1].
"La toillete" oil on canvas was finished in 1870 just before Bazille's death (Fig. 1). It presents a French art model Lise Trehot, but for us more interesting is a mysterious woman on the right side. We see clearly large, smooth goiter. No eye signs, but slim woman's stature does not help with differentiation between simple goiter and Graves' disease. Historically, goiter seems to be "older" disease (i.e., paintings of Flemish or Italian Renaissance painters) but this question will be unanswered [2,3].

According to Encyclopaedia Brittanica, Bazille was an unenthusiastic medical student. I strongly deny this opinion when I see such perfect thyroid. I hope every student have Bazille's perception [4].

L. Obolonczyk

przepona@wp.pl

1 Department of Endocrinology and Internal Medicine, Medical University of Gdansk, Debinki 7 Street, 80-952 Gdansk, Poland 
Fig. 1 La Toilette (December 1869-March 1870), by Frederic Bazille, oil on canvas $153 \times 148.5 \mathrm{~cm}$ [Musee Fabre, Montpellier, France]. Please note large goiter on first right lady

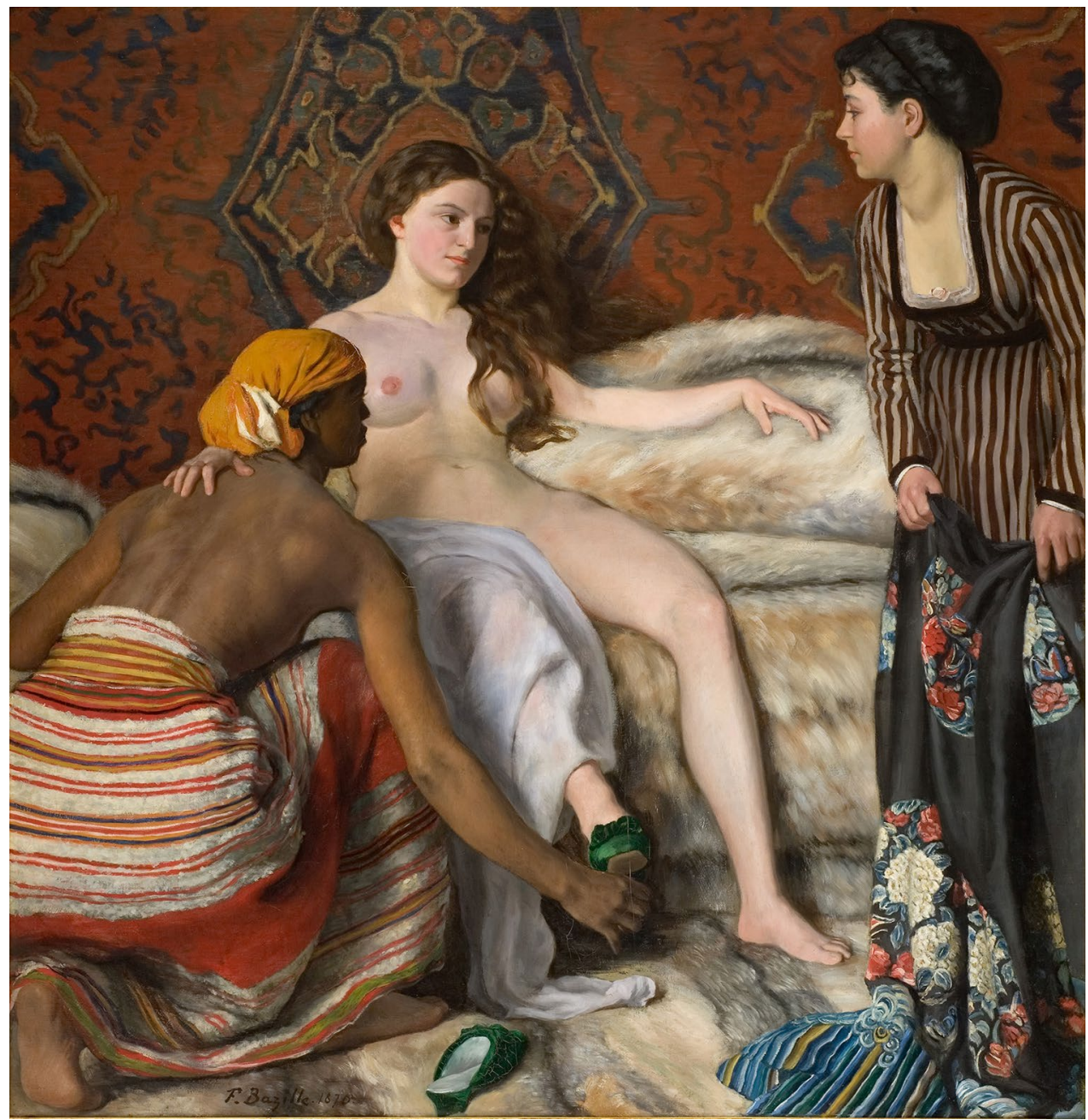

\section{Compliance with ethical standards}

Conflict of interest On behalf of all the authors, the corresponding author states that there is no conflict of interest.

Ethical approval This paper does not contain any studies with human participants or animals performed by any of the authors.

Informed consent No informed consent.

Open Access This article is distributed under the terms of the Creative Commons Attribution 4.0 International License (http://creativeco mmons.org/licenses/by/4.0/), which permits unrestricted use, distribution, and reproduction in any medium, provided you give appropriate credit to the original author(s) and the source, provide a link to the Creative Commons license, and indicate if changes were made.

\section{References}

1. Jourdan A (1992) Frédéric Bazille: prophet of impressionism. Publisher: Brooklyn Museum Bookshop; First edition (November 1, 1992)

2. Lazzeri D, Pozzilli P, Zhang YX, Persichetti P (2015) Goiter in paintings by Rogier van der Weyden (1399-1464). Thyroid 25(5):559-562

3. Sterpetti AV, Fiori E, de Cesare A (2016) Goiter in the Art of Renaissance Europe. Am J Med. 129(8):892-895

4. Encyclopaedia Brittanica. https://www.britannica.com/biography/ Frederic-Bazille. Accessed 07 Mar 2019

Publisher's Note Springer Nature remains neutral with regard to jurisdictional claims in published maps and institutional affiliations. 